D.G. Koliushko, S.S. Rudenko, S.V. Kiprych

\title{
ANALYSIS OF THE STATE OF THE EXTERNAL LIGHTNING PROTECTION SYSTEM FOR OPERATING ENERGY OBJECTS
}

Introduction. Within the framework of European integration of Ukraine, the international Standard IEC 62305 has been harmonized, which provides for a full inspection of lightning protection devices with a frequency of $0.5-4$ years, which significantly increases the volume of work. Problem. The adopted Standard is stricter than those for which external lightning protection systems (LPS) of power plants and substations, which are objects of critical infrastructure, have been designed. There is no clear algorithm of actions to bring the existing LPS of existing energy facilities of Ukraine in accordance with the requirements of IEC 62305. Due to the need to modernize the existing LPS facilities, there is a need to develop a single algorithm for these works. Goal. Development of an algorithm for evaluation of the current state LPS for existing power plants and substations. Methodology. Based on the analysis of IEC 62305, three stages of evaluation are proposed: experimental (based on geodetic and electromagnetic method of determining the configuration of the object and components of LPS), calculation (based on the topographic survey method and the electromagnetic method for determining the configuration of the object and components of the LPS) and stage of analysis and development of recommendations. Results. Three stages, which are a basis of analysis of a condition of LPS based on the created algorithm, are considered in detail. An example of the analysis LPS condition of the existing substation with a voltage of $35 \mathrm{kV}$, created according to the specified method, is given. The program report in $3 D$ form illustrates the unprotected parts of the object. Originality. For the first time, an algorithm for analysis the state of LPS of operating energy facilities according to the IEC 62305 standard has been developed. Practical value. Typical remarks to the existing LPS are formed. The results of the work can be used to inspection and modernize the LPS energy facilities, as well as buildings and structures of public importance. References 18, tables 1, figures 3.

Key words: lightning protection, protection zone, lightning rod, energy facility, rolling sphere method.

В роботі запропоновано алгоритм аналізу стану системи блискавкозахисту (СБ3) діючих енергооб'єктів, який складається 3 трьох етапів: експериментального (на основі топографічного та електромагнітного методу визначення конфігурації об'єкту й компонентів СБ3), розрахункового (визначення зони захисту стандартним електрогеометричним методом) й етапу аналізу та розробки рекомендацій. До існуючих СБЗ сформовано типові зауваження та заходи щцодо ̈̈х усунення відповідно до вимог ДСТУ ЕN 62305. Результати роботи можуть бути використані для перевірки та модернізації СБЗ складних промислових та енергетичних об'єктів, а також будівель $i$ споруд загальносуспільного значення. Бібл. 18, табл. 1, рис. 3.

Ключові слова: блискавкозахист, зона захисту, блискавкоприймач, енергооб'єкт, метод сфери, що котиться.

В работе предложен алгоритм анализа состояния системы молниезащиты (СМЗ) действующих энергообъектов, состоящий из трех этапов: экспериментального (на основании топографического и электромагнитного метода определения конфигурации объекта и компонентов СМЗ), расчетного (определение зоны зациты стандартным электрогеометрическим методом) и этапа анализа и разработки рекомендаций. К существующим СМЗ сформулированы типовые замечания и меры их устранения в соответствии с требованиями ДСТУ ЕN 62305. Результаты работы могут быть использованы для проверки и модернизации СМЗ сложных промышленных и энергетических объектов, а также зданий и сооружений общественного назначения. Библ. 18, табл. 1, рис. 3.

Ключевые слова: молниезащита, зона защиты, молниеприемник, энергообъект, метод катящейся сферы.

Analysis of publications. Within the framework of European integration measures, in Ukraine the international Standard on lightning protection was harmonized [1], the requirements of which differ significantly from the Standards of the USSR [2] and Ukraine [3], according to which the design and control of the lightning protection system (LPS) of the vast majority of existing strategic energy facilities in Ukraine have been carried out.

According to [1] the LPS should be inspected:

- during installation of the LPS;

- after installation of the LPS;

- systematically, according to Table 1 .

The time intervals listed in Table 1, should be applied in the absence of additional instructions of regulatory documents.

The frequency of inspection of the LPS is determined taking into account the following factors:

- classification of the protected object (power plant, substation, etc.), especially taking into account possible damages;

- LPS class;

- environment depending on the degree of its aggressiveness;
- material of individual components of the LPS;

- soil characteristics and degree of corrosion;

- weather conditions (changes in temperature and precipitation);

- changes in the parameters of the grounding device (GD) depending on humidity and temperature (e.g. resistance).

Table 1

Maximum interval between LPS inspections, year

\begin{tabular}{|c|c|c|c|}
\hline $\begin{array}{c}\text { Protection } \\
\text { level }\end{array}$ & $\begin{array}{c}\text { Visual } \\
\text { audit }\end{array}$ & $\begin{array}{c}\text { Full } \\
\text { audit }\end{array}$ & $\begin{array}{c}\text { Critical situations } \\
\text { (full inspection) }\end{array}$ \\
\hline I and II & 1 & 2 & 1 \\
\hline III and IV & 2 & 4 & 1 \\
\hline $\begin{array}{l}\text { Note. In buildings where there is a possibility of an explosion, } \\
\text { inspections should be carried out every six months. Critical situations } \\
\text { may include buildings (structures) that contain sensitive internal } \\
\text { systems, office buildings, commercial buildings, or places where a } \\
\text { significant number of people may be present. }\end{array}$ \\
\hline
\end{tabular}

The LPS should also be inspected on an ongoing basis if significant changes have been made or the protected object has been reconstructed, as well as after lightning discharges.

(C) D.G. Koliushko, S.S. Rudenko, S.V. Kiprych 
The harmonized International lightning protection Standard [1] has more stringent requirements for lightning rods (LRs) protection zones than [2], [3] and other design requirements.

In this regard, the urgent problem is to inspect the LPS of existing energy facilities for compliance with the norms. The normative document itself specifies the parameters that need to be checked, but there is no explanation of the sequence and methods of verification.

In addition, the analysis of the state of LPS of complex objects, which are power plants and substations, is practically not considered. On their territory there is a large number of LRs of different types (rods, cables, nets), which create a connection between them. In addition, lightning protection of energy facilities is a strategic task, because the failure of equipment can lead to both costly repairs and significant losses from power outages of important consumers.

The analysis of the existing literature, in particular [4-8], shows that the assessment of the current state of the LPS of energy facilities in the form of a clear sequence of interrelated methods of inspection of the LPS is absent. Usually, publications are devoted to the calculation of LR protection zones or the design of LPS in accordance with [1].

The goal of the work is to develop an algorithm for assessing the current state of the LPS of existing power plants and substations.

Research materials. Due to the fact that the implementation of the inspection of the LPS [1] includes field and in-house work, and the main result is the development of recommendations for the arrangement of the LPS in accordance with regulatory requirements, the analysis of the current state of the SBZ is presented in three stages:

- obtaining initial data on the arrangement of the existing LPS (experimental stage performed in the field);

- determination of the level of the LPS and calculation of protection zones (PZs) of lightning rods (calculation stage);

- analysis of the existing LPS and development of necessary measures for protection of the object with minimization of material and labor costs (stage of analysis and development of recommendations).

Consider each of the stages of the analysis of the LPS more in detail.

1. Experimental stage. The lightning protection system consists of lightning rods, current collectors and GD.

During this stage, the following is determined:

1) geometric configuration of the LPS and the protected object;

2) general condition of LPS components (configuration, material, cross-section, quality of electrical connections, corrosion level);

3) value of the equivalent resistivity of the soil;

4) resistance of the GD of the LR with a separate ground rod.

For the listed items it is necessary to carry out field works on restoration (creation) of executive documentation. This is due to the long-term operation of the facility, during which it undergoes significant changes (installation of the communication masts, damage to the structure of the LR, expansion of the facility, corrosion infuence, etc.) and the loss of executive documentation.

When determining item 1 of the experimental stage, measurements of the geometric configuration of the protected object and the LPS by topographic surveying methods (for example, by theodolite one) are carried out [9]. The overall dimensions and height are marked on the map at a scale convenient for further work. The biggest difficulties of this item are:

- need to determine and further take into account the difference in ground level and height of parts of the object and the LPS relative to it;

- presence of high-rise buildings outside the facility, which may create additional PZ.

The work according to item 2 of the experimental stage is performed using:

- direct measurements with a caliper (cross-section of LPS conductors);

- induction method (GD configuration);

- ammeter-voltmeter method (quality of electrical connections).

Figure 1 shows a plan of the object with its LPS on the example of one of the substations with voltage class of $35 \mathrm{kV}$, which is the result of items 1,2 .

The work according to item 3 of the experimental stage is performed by the method of vertical electric sounding (using the Wenner or Schlumberger arrangement), and according to item 4 - by the ammetervoltmeter method (by potential drop, four-point or $« 62 \%$ method») [10].

In general, the work for items $2-4$ is performed according to the method described in [11] and according to the procedures described in [12].

All the difficulties of these substages correspond to the problems described in [13]. The most important of them:

- determining the condition of LPS conductors, such as current collectors, at a height near current carrying parts at power plants and substations (often in this case the only way to check is the use of photographic equipment, preferably with a long-focus lens);

- laborious work on finding grounding conductors in the soil and ways of lightning current spreading;

- practical complexity of identification of vertical electrodes and impossibility to determine their length and cross-section.

In addition, in [14] there is no concept of pulses resistance [15], in contrast to [1], so for it 4 the international method of determining the impedance using the appropriate devices considered, for example, in [16] should be used.

The results of measuring the geometric configuration of objects and their LPS are plotted on the diagram in electronic form. Data on deviations from the requirements of the Standard, changes and deformations of the LPS and any changes in the object must be recorded both in text form and with the help of photo and video equipment. The results of the experimental stage are recorded in the reporting documentation. 


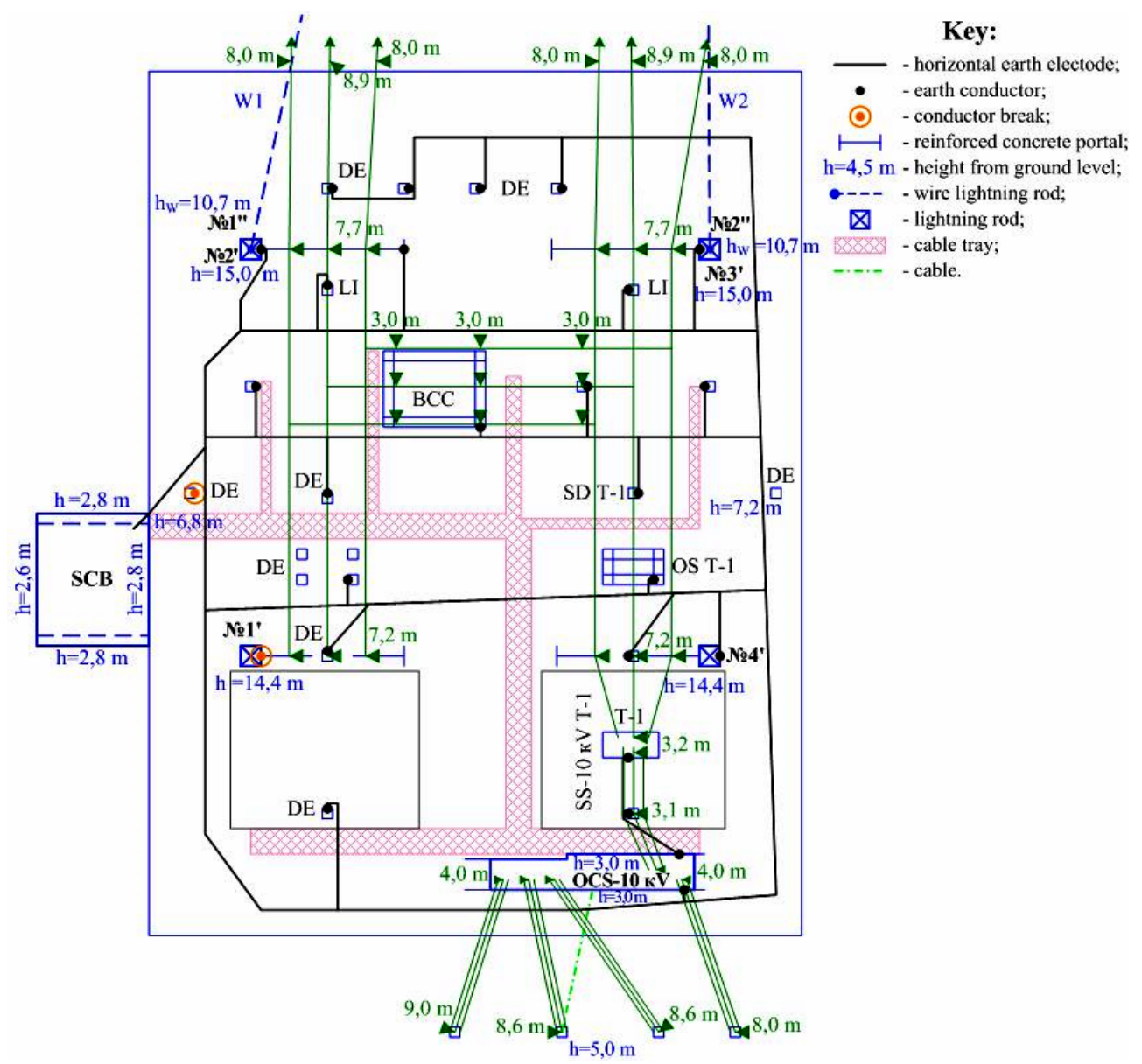

Fig. 1. Plan of the object and its LPS

2. Calculation stage. The calculation stage begins with determining the level of LPS, which is performed based on the calculation of the risk of lightning strikes to the object and the characteristics of the object. This is usually based on information provided by the operating organization and/or template calculations set out in some national annexes to IEC 62305 (e.g. in Germany).

Then, with the help of a special computer code, the calculation of the PZ of the LR is performed and the report is obtained in 2D and 3D form. To do this, first calculate the calculation scheme of the LPS is prepared, which includes the protected object. The scheme should take into account for the current time the following:

- LPS level (sphere radius is $20 \mathrm{~m}, 30 \mathrm{~m}, 45 \mathrm{~m}$ or $60 \mathrm{~m}$ for LPS of classes I, II, III or IV, respectively);

- location of the LR on the scheme (coordinates and height of each LR);

- location of buildings and structures of the protected object (coordinates and height).

To perform calculations, the method of determining the PZ of the LR using the rolling sphere method for one or 2-3 rod LRs of the same height [17] or computer codes to build the PZ of the LR of arbitrary heights and locations (e.g., Pentair, ERICO, Entegra, Primtech) can be used.

Experts of NTU «KhPI», using the mathematical apparatus given in [18], developed a computer system «LiGro», which is intended to calculate and design grounding and lightning protection systems. Regarding the calculation of the LPS the system consists of three logical parts:

- graphic editor, which allows to place on the scheme as many large numbers as you like of buildings, structures and LR of any shape on a real scale using a graphical interface (location and size);

- 2D report, with which it is possible to analyze the results of the calculation of the PZ of the LR on the plane;

- 3D report for the analysis of the results of the calculation of the PZ of the LR in space.

Figure 2,a shows the object and its LPS in 3D, and in Fig. 2,b presents the result of the calculation of the PZ of the external LPS of the substation with the system «LiGro» in 3D in accordance with [1] and marks places that are outside the protection zone: $10 \mathrm{kV}$ busbars (1); part of the fence (2); KRUZ-10 kV (3) and busbar $35 \mathrm{kV}$ (4). Therefore, to protect the object from direct lightning strikes, it is necessary to develop recommendations (install additional LRs of the required height).

3. Stage of analysis and development of recommendations. The calculation scheme does not change if it is recommended to use only a protective grid made in accordance with the requirements of the regulatory document [1] to protect the object (or part of it).

If the object is not protected from direct lightning strikes, i.e. it or its parts are outside the PZ of the LR system, then the recommended LRs needed to protect the entire object should be added to the calculation scheme. The location, height and design of the recommended LRs should be chosen taking into account the economic feasibility and technical feasibility. Therefore, the development of recommendations for the installation of additional LRs is iterative in nature, aimed at finding optimal solutions: the installation, if possible, of typical LRs with the minimum required number and height. After 
that it is necessary to check that all constructions are inside the PZ of the LR system, and also to analyze the constructive implementation of the LPS. If necessary, provide recommendations for bringing the constructive implementation of the LPS to the requirements of

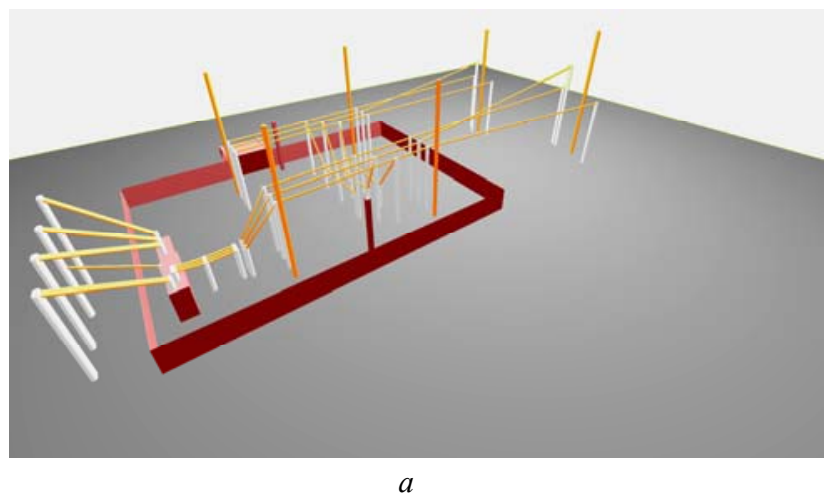

regulatory documents with the subsequent registration of all stages of work in the form of reporting documentation.

Thus, the assessment of the current state of the LPS of the existing energy facility can be represented as an algorithm (Fig. 3).

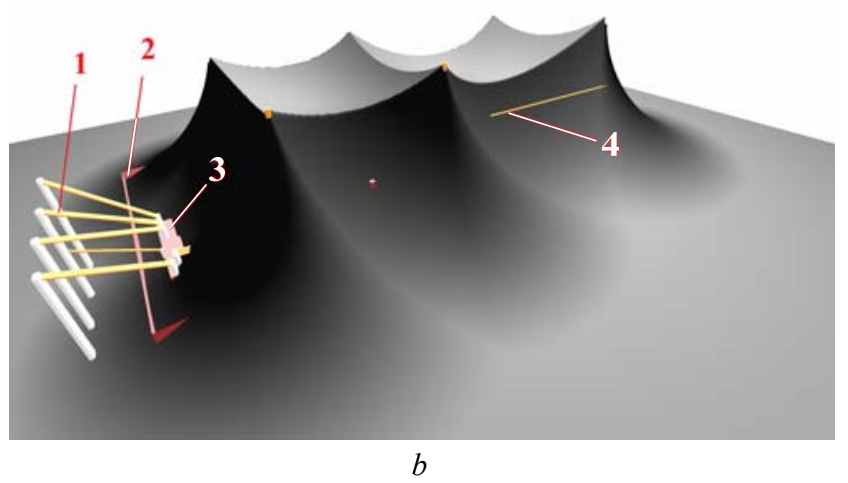

Fig. 2. Report in 3D

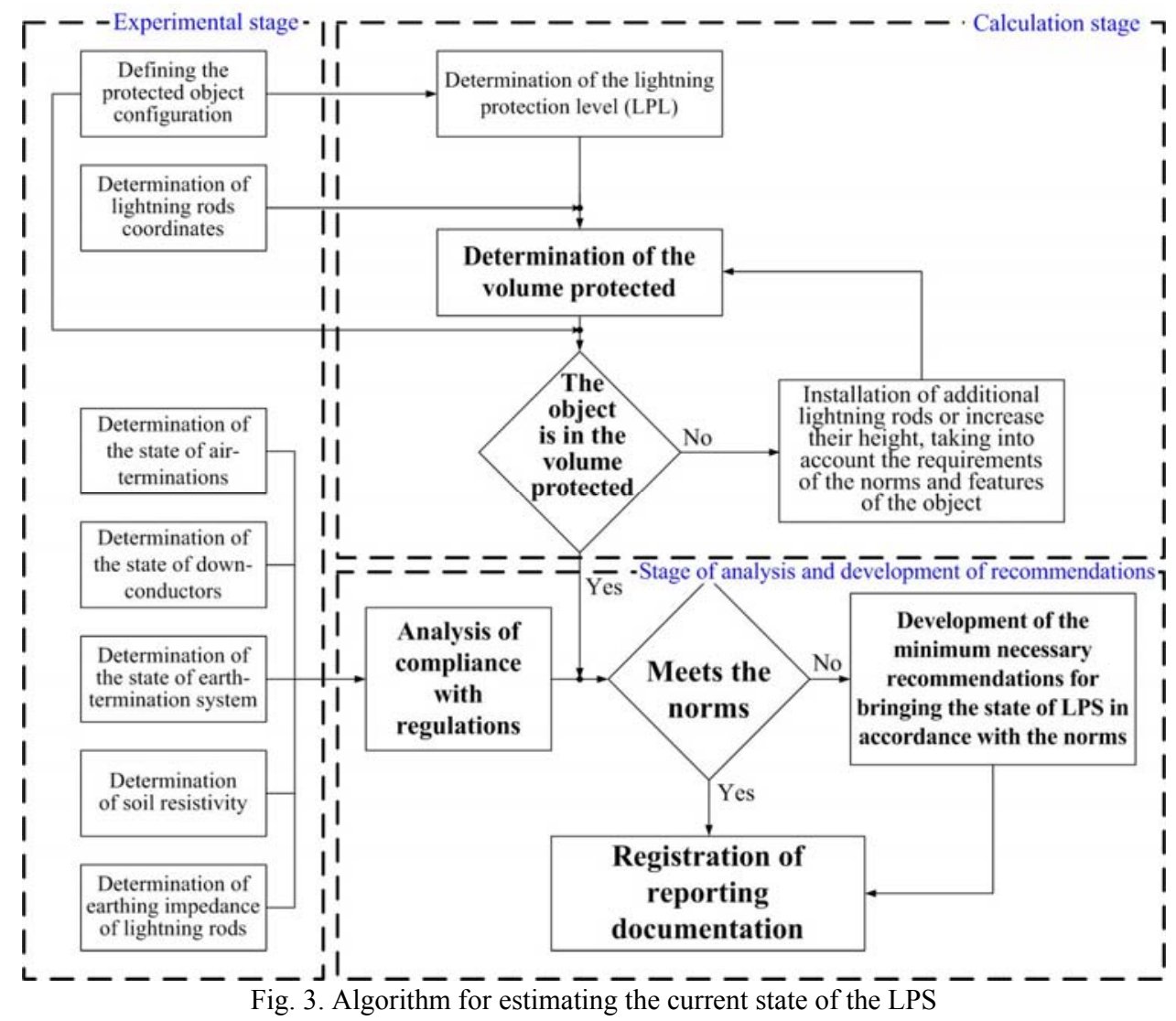

The developed algorithm was successfully used at more than 200 power plants and substations of voltage classes of $35-750 \mathrm{kV}$. According to the results of the analysis of the current state of the LPS, standard remarks were formed to:

- security of objects (buildings and structures or their parts are outside the PZ of the LR; antennas and other communication devices that are sensitive to lightning surges, which are installed on lightning rods and buildings/structures that are not protected from direct lightning);

- lightning rods (the cross section is smaller $50 \mathrm{~mm}^{2}$; no galvanic connection to the current drain; corrosion damage; deformation of the structure);

- current drains (no artificial current drains; the crosssection is less than $50 \mathrm{~mm}^{2}$; the natural current drain has no galvanic connection with the lightning rod and grounding device; corrosion damage);

- grounding device (resistance exceeds the regulated value; design and/or cross-section does not meet the requirements of regulatory documents);

- installation of lightning rods (performed in violation of the requirements of regulatory documents - the distance to the current carrying parts, grounded structures and grounding device of the substation is less than regulated one);

- electrical wiring (cables are laid in violation of regulatory requirements; cables from lighting equipment installed on the LR go to buildings/structures, which can lead to high potential during lightning strikes in the LR; cables that go from buildings/structures to the territory of the protected object, are outside the PZ of the LR, which 
can lead to the entry of high potential into the building/structure during a lightning strike in these cables outside the territory of the protected object).

In order to eliminate remarks and bring the state of the LPS in accordance with the requirements of regulatory documents, the recommendations based on the results of the analysis of the state of the LPS of energy facilities may include the following items:

1. Installation of additional rod lightning rods or LRs of the required height:

- located separately;

- on portal constructions;

- on a building or structure.

2. Laying current leads from lightning rods to grounding conductors.

3. Ensuring galvanic connection of the cable lightning rod with the cable stand.

4. Laying additional horizontal grounding conductors in the recommended LRs to ensure the spread of lightning current by the grounding conductor in accordance with the requirements of regulatory documents.

5. Connection to the common GD of the substation of portal structures with rod and cable LRs, searchlight masts and lighting towers.

6. Connection to the common GD, if necessary, of the LR with a separate grounding conductor.

7. Installation of vertical electrodes in accordance with the requirements of regulatory documents.

8. To protect the buildings at the substation from direct lightning strikes - laying a protective net around the perimeter of the roof (as close as possible to its edge). To prevent thermal destruction of the roof waterproofing coating (roofing felt), it is recommended to secure the protective net conductors with roof holders (stands) made of heat-resistant material (e.g. concrete, clay, etc.).

9. Execution of electrical wiring to lighting equipment installed on floodlight masts in accordance with the requirements [14].

10. Replacement of corroded LPS components.

Then the results of all stages are systematized with registration in the form of documentation for external LPS (protocol, passport, report, etc.).

The documentation (in any form) must contain an explanatory note and graphic material.

\section{Conclusions.}

1. The paper describes for the first time the stages of analysis of the current state of the LPS of operating energy facilities of Ukraine and its components, an evaluation algorithm is developed, and methods for performing each of the stages are proposed.

2. The standard remarks to the LPS of the objects which are in operation are analyzed and systematized.

3. Possible measures are provided to eliminate the shortcomings identified in the process of analysis of the state of the LPS.

\section{REFERENCES}

1. State standard of Ukraine EN 62305:2012 Protection against lightning. (IEC 62305: 2011, IDT). Kyiv, State Standard of Ukraine, 2012. 419 p. (Ukr).

2. Guidelines for installation of lightning protection systems for buildings and structures ( $R D$ 34.21.122-87). Moscow, Energoatomizdat Publ., 1989. 56 p. (Rus).
3. DSTU B V.2.5-38:2008 Lightning protection device for buildings and structures (IEC 62305:2006 NEC). Kyiv, Minrehionbud Ukraine Publ., 2008. 63 p. (Ukr).

4. Lyutarevich A.G., Basmanovskiy M.A., Sershanskiy V.P., Zhilenko E.P. Investigation of lightning protection of open switchgears of power stations and substations. Omsk Scientific Bulletin, 2018, no. 162, pp. 61-66. doi: 10.25206/1813-82252018-162-61-66.

5. Dyakov A.F., Kuzhekin I.P., Maksimov B.K., Temnikov A.G. Electromagnetic compatibility and lightning protection in the power. Moscow, MEI Publishing House, 2009. 455 p. (Rus).

6. Rizk F.A.M. Modeling of substation shielding against direct lightning strikes. IEEE Transactions on Electromagnetic Compatibility, 2010, vol. 52, no. 3, pp. 664-675. doi: 10.1109/TEMC.2010.2046903.

7. Kazanskiy S.V, Maltsev V.V 3D-modeling of lightning Protection systems of electrical network. Power engineering: economics, technique, ecology, 2014, no. 4 (38), pp. 78-83. (Ukr).

8. Analysis of modern foreign and domestic experience in the installation of lightning protection systems of the electrical objects. Kyiv, National Power Company «Ukrenergo», 2012. 75 p. (Ukr).

9. Kern R. Wissenschaftliche Instrumente in ihrer Zeit/Band 4. Perfektion von Optik und Mechanik. Cologne, 2010, pp. 349360. (Ger).

10. IEEE Std 81-2012 Guide for Measuring Earth Resistivity, Ground Impedance, and Earth Surface Potentials of a Grounding System. New York, IEEE, 2012. 86 p. doi: 10.1109/ieeestd.2012.6392181.

11. Koliushko D.G., Rudenko S.S. Analysis of methods for monitoring of existing energy objects grounding devices state at the present stage. Electrical engineering \& electromechanics, 2019, no. 1, pp. 67-72. doi: 10.20998/2074-272X.2019.1.11.

12. National Standard of Ukraine SOU 31.2-21677681-19:2009.

Test and control devices, electrical grounding. Standard instruction. Kyiv, Minenergovugillya Ukrayiny Publ., 2010. 54 p. (Ukr).

13. Koliushko G.M., Koliushko D.G., Rudenko S.S. On the problem of increasing computation accuracy for rated parameters of active electrical installation ground grids. Electrical engineering \& electromechanics, 2014, no. 4, pp. 65-70. (Rus). doi: 10.20998/2074-272X.2014.4.13.

14. Electrical installation regulations. Kharkiv, Fort Publ., 2017. 760 p. (Ukr).

15. Grcev L., Markovski B. Impulse impedance and effective area of grounding grids. IEEE Transactions on Power Delivery, 2020, pp. 1-10. doi: 10.1109/tpwrd.2020.3003427.

16. Koliushko D.G., Rudenko S.S., Plichko A.V., Shcherbinin V.I. Modernization of the complex type IK-1U for measuring the impedance of the grounding device of a lightning arrester and supports of transmission lines. Electrical engineering \& electromechanics, 2019, no.3, pp. 55-58. doi: 10.20998/2074272X.2019.3.09.

17. Petcharaks N. Lightning protection zone in substation using mast. KKU engineering journal, 2013, vol. 40, no. 1, pp. 11-20. doi: 10.5481/kkuenj.2013.40.1.2.

18. Koliushko D.G., Istomin O.Y., Rudenko S.S., Kiprych S.V. Mathematical model of the protection zone during an arbitrary configuration of the air-termination rods location. Technical Electrodynamics, 2020, no. 1, pp. 3-9. (Ukr). doi: 10.15407/techned2020.01.003.

Received 01.08.2020

D.G. Koliushko ${ }^{1}$, Candidate of Technical Science, Senior

Research Scientist,

S.S. Rudenko ${ }^{1}$, Candidate of Technical Science, Senior Research Scientist,

S.V. Kiprych ${ }^{1}$

${ }^{1}$ National Technical University «Kharkiv Polytechnic Institute», 2, Kyrpychova Str., Kharkiv, Ukraine, 61002,

e-mail: nio5_molniya@ukr.net

How to cite this article:

Koliushko D.G., Rudenko S.S., Kiprych S.V. Analysis of the state of the external lightning protection system for operating energy objects. Electrical engineering \& electromechanics, 2020, no. 5, pp. 66-70. doi: 10.20998/2074-272X.2020.5.10. 